\title{
RESPONSABILIDADE TRIBUTÁRIA DE GRUPOS ECONÔMICOS E O INCIDENTE DE DESCONSIDERAÇÃO DA PERSONALIDADE JURÍDICA NO NCPC
}

Leonardo Nuñez Campos

\section{INTRODUÇÃO}

A edição da Lei n. 13.105/2015 introduziu no ordenamento jurídico brasileiro o Novo Código de Processo Civil (NCPC), substituindo o Código de Processo Civil de 1973 (CPC/73). Dentre as diversas inovações promovidas no sistema processual está o incidente de desconsideração da personalidade jurídica (IDPJ), que traz um procedimento próprio visando garantir o devido processo legal substantivo no caso de aplicação da disregard doctrine.

O presente artigo tem como objeto a verificação da possibilidade de utilização do IDPJ nas execuções fiscais, especialmente nos casos em que há a responsabilização pelo pagamento do crédito tributário de empresas partícipes de grupos econômicos. Para alcançar o objetivo proposto, a análise será dividida em duas etapas. Após esta introdução, os itens 2 e 3 buscarão analisar o que são os grupos econômicos e quais as hipóteses de responsabilização dos seus componentes pelo pagamento de tributos. Em seguida, o item 4 tratará dos problemas inerentes ao redirecionamento de execuções fiscais, expondo as mitigações ao contraditório decorrente da prática judicial. Por fim, o item 5 analisará o IDPJ, abordando detalhes sobre o instituto e a sua aplicabilidade nas execuções fiscais, para, então, verificar se nos casos autorizados de redirecionamento para empresas que participam de grupo econômico é necessária a aplicação do IDPJ. 


\section{GRUPOS ECONÔMICOS: CLASSIFICAÇÃO E CONCEITO}

O tema objeto do presente capítulo - a responsabilidade tributária de grupos econômicos - é um dos problemas que se situa exatamente na interseção entre dois ramos da ciência do direito: o direito público e o direito privado, especificamente o direito tributário e o direito societário.

A imprecisa definição do que seriam "grupos econômicos", tema inicialmente afeito ao direito societário, e as lacunas na legislação quanto às hipóteses de responsabilização dos grupos por débitos de natureza fiscal, tema afeito ao direito tributário, geram enorme insegurança para os agentes econômicos que se organizam para explorar negócios por meio de empresas plurissocietárias. Essa forma de organização empresarial é responsável por parcela vultosa dos negócios realizados no Brasil e no mundo. As variadas alternativas de organização societária das empresas representam, para os legisladores e para os intérpretes do direito, imensas dificuldades de conceituação, sistematização e classificação desses grupos. A diversidade é tanta que Claude Champaud ${ }^{1}$ chega a afirmar que "existem atualmente tantos tipos de grupos econômicos quanto os próprios grupos".

A dinâmica organização das empresas, embora seja uma realidade inafastável, ${ }^{2}$ pode causar perplexidade aos estudiosos de direito na medida em que põe em xeque aquilo que o português Engrácia Antunes denominou "vacas sagradas" do direito das sociedades comerciais: os dogmas da personalidade jurídica da sociedade comercial e da limitação de responsabilidade dos sócios. ${ }^{3}$ Os legisladores, então, passaram a implementar formas de regulação dos grupos para que os problemas decorrentes desse tipo de organização de empresa fossem minorados, já que o direito societário clássico não trazia as respostas adequadas

1 CHAMPAUD, Claude apud MEIRELES, Edilton. Grupo Econômico Trabalhista. São Paulo: LTR, 2002.

2 Danilo Borges dos Santos Gomes de Araújo e Walfrido Warde Jr. afirmam que: "Hoje, não seria absurdo dizer que os grupos representam o grosso daqueles fenômenos econômicos-sociais que estão na esfera do direito societário, ainda que os textos legislativos acanhem-se em assim se expressar. Algum laconismo legislativo é suprido pelos cada vez mais abundantes precedentes jurisprudenciais, pela já consolidada doutrina, e, sobretudo, pelos maneirismos e pelos interesses do homem de empresa" (ARAUJO, Danilo Borges dos Santos Gomes de; WARDE JR., Walfrido. Os grupos de sociedades: organização e exercício da empresa. São Paulo: Saraiva, 2012).

3 ANTUNES, José Engrácia. Estrutura e responsabilidade da empresa: o moderno paradoxo regulatório. Revista Direito GV, v. 1, n. 2, p. 29-68, jun.-dez. 2005. 
para a solução dos conflitos. ${ }^{4}$ Essa regulação se deu de forma diferente em cada país, mas pode ser resumida em dois modelos básicos: o modelo contratual e o modelo orgânico.

O modelo contratual de regulação dos grupos de sociedades (konzern) foi inaugurado pela Alemanha por meio da Lei Societária Alemã de 1965 (Aktiengesets). Esse modelo, adotado de forma semelhante em Brasil, Portugal, Croácia, Eslovênia e Taiwan, ${ }^{5}$ tem como característica principal a normatização do tema a partir da natureza do instrumento jurídico de constituição do grupo. ${ }^{6}$ A característica marcante desse modelo é a existência de regulação para a formação e a atuação dos grupos de sociedade, que devem ser constituídos por meio de um instrumento de contrato no qual estejam claras as regras de funcionamento e a relação entre as sociedades que o compõem.

Já a forma de regulação do modelo orgânico parte do pressuposto de que os grupos de sociedade têm sua existência decorrente da constatação de que uma sociedade se relaciona com outras por uma relação de subordinação a uma direção econômica unitária comum, não sendo relevante a formalização a partir de nenhum instrumento de constituição específico. ${ }^{7}$ É esse o modelo constante nos projetos de Estatutos da Sociedade Anônima Europeia (SAE) e no Projeto de $9^{a}$ Directiva Comunitária relativa aos grupos de sociedades (PDC). ${ }^{8}$

Tal modelo também prevê a existência de normas que "em derrogação dos cânones clássicos do direito das sociedades, vêm legitimar o exercício de um poder de direcção por uma sociedade-mãe sobre as sociedades-filhas agrupadas", além

4 NUNES, Gonçalo Nuno Cabral de Almeida Avelãs. Tributação dos grupos de sociedades pelo lucro consolidado em sede de IRC: contributo para um novo enquadramento dogmático e legal do seu regime. Coimbra: Almedina, 2001.

5 NUNES, Gonçalo Nuno Cabral de Almeida Avelãs. Tributação dos grupos de sociedades pelo lucro consolidado em sede de IRC: contributo para um novo enquadramento dogmático e legal do seu regime. Coimbra: Almedina, 2001.

6 ANTUNES, José Engrácia. Os grupos de sociedade: estrutura e organização da empresa plurissocietária. 2. ed. rev. e atual. Coimbra: Almedina, 2002.

7 ANTUNES, José Engrácia. Os grupos de sociedade: estrutura e organização da empresa plurissocietária. 2. ed. rev. e atual. Coimbra: Almedina, 2002.

8 A última versão dos projetos do SAE já não continha nenhum capítulo tratando dos grupos, enquanto as propostas do PDC nunca chegaram a ser aprovadas. NUNES, Gonçalo Nuno Cabral de Almeida Avelãs. Tributação dos grupos de sociedades pelo lucro consolidado em sede de IRC: contributo para um novo enquadramento dogmático e legal do seu regime. Coimbra: Almedina, 2001. 
de "estabelecer a tutela para estas sociedades, respectivos sócios e credores". ${ }^{9}$ Portanto, diferente do modelo contratual, a essência da realidade de controle é o fator preponderante para a definição do que é o grupo societário no modelo orgânico.

O legislador brasileiro não passou ao largo da realidade econômica da organização empresarial plurissocietária, sendo possível identificar, em diversos extratos legislativos, menções tendentes a regular a atividade dos grupos de empresas. Existe, entretanto, uma falta de sistematização do tema, de modo que cada segmento da legislação trata do assunto de forma distinta, trazendo grandes confusões conceituais que precisam ser enfrentadas. Pode-se, então, afirmar que não há um conceito unitário trazido pela legislação para regulamentar a matéria ${ }^{10} \mathrm{de}$ forma que cada ramo do direito vem a tratar do tema da forma que mais the convém para o regramento das condutas dos indivíduos. ${ }^{11}$

O Decreto-Lei n. 5.452/1943 (Consolidação das Leis do Trabalho - CLT), por exemplo, utiliza a classificação baseada na atividade principal das empresas do grupamento, tendo utilizado o termo "grupo industrial, comercial ou de qualquer atividade econômica", que seria constituído no caso de empresas estarem "sob

9 ANTUNES, José Engrácia. Os grupos de sociedade: estrutura e organização da empresa plurissocietária. 2. ed. rev. e atual. Coimbra: Almedina, 2002. p. 178.

10 "Defende-se, portanto, a não-unidade do conceito de grupo de sociedades de forma a ser aplicado a todo o sistema jurídico. Cada ramo do direito deve estabelecer os elementos específicos, levando em consideração os objetivos a serem atingidos, existindo, assim, definições diferentes no direito societário, no direito da concorrência, no direito do trabalho e no direito tributário. Ademais, no próprio direito societário há diversas perspectivas, pois pode-se buscar tanto a proteção do patrimônio social, dos credores e dos sócios externos como ter em vista os deveres de informação e critérios contábeis, a insolvência, as normas penais societárias, a desconsideração da personalidade juridica e até mesmo o aspecto orgânico do grupo como tal" (PRADO, Viviane Muller. Conflito de interesses nos grupos societários. São Paulo: Quartier Latin, 2006, p. 153).

11 Essa ideia está presente nos escritos de Gunther Teubner: "Exigências mínimas de segurança jurídica poderiam ser satisfeitas através da previsão de um conjunto de elementos típicos e fixos do conceito de grupo, comuns a todos os ramos jurídicos, designadamente em matéria de direcção unitária do grupo. Todavia, uma vez verificada esta condição mínima comum, os critérios de imputação deveriam permanecer flexiveis e determináveis de acordo com o contexto juridico concreto em causa. Finalmente, poder-se-ia evitar a degradação de uma tal técnica de imputação múltipla numa arbitrária 'Kadijustiz' caso se salvaguardasse a sua orientação pelas máximas seguintes: manutenção das vantagens organizacionais da descentralização e eficácia regulatória enquanto implementação dos objetivos político-jurídicos das normas" (TEUBNER, Gunther. Unitas miltiplex: a organização do grupo de empresas como exemplo. Revista Direito GV, v. 1, n. 2. p. 77-100, jun.-dez. 2005. p. 98). 
direção controle ou administração de outras". O grupo, então, é identificado por critério orgânico, não em função da existência de contrato. Já a Lei n. 6.404/1976 (Lei das S/A), influenciada pela lei societária alemã de $1965,{ }^{12}$ traz regulação do tema adotando o modelo contratual, que resulta na existência de dois tipos que podem ser distinguidos pela classificação da doutrina em "grupos de fato" (Capítulo XX) e "grupos de direito" (Capítulo XXI).

O direito tributário também não passou ao largo da realidade econômica, havendo distintas normas que abordam a relação das empresas agrupadas. Podem-se citar: (i) a Lei n. 5.502/1964 (Lei do IPI), que trata de "firmas interdependentes"; (ii) o Decreto-Lei n. 1.598/1977,13 que possibilitou a tributação conjunta do Imposto de Renda no caso de grupos e trouxe regras para combater de distribuição disfarçada de lucros entre "pessoas ligadas"; (iii) a Lei n. 12.249/2010, na parte que trata das regras de combate dos efeitos da subcapitalização; (iv) a Lei n. 9.430/1996, no que se refere aos preços de transferência; (v) a Solução de Consulta n. 08/2012 e a Solução de Divergência n. 23/2012, ambas da Coordenação Geral de Tributação (Cosit) da Secretaria da Receita Federal do Brasil, que trataram de esclarecer a possibilidade de sociedades firmarem contratos de rateio de despesas (costsharing) para dividir aqueles custos que são comuns às empresas do grupo; (vi) o art. $33^{14}$ da Lei n. 13.043/2014, convertida a partir da Medida Provisória (MP) n. 651/2014, que considerou a existência de grupos para permitir a transferência

12 PRADO, Viviane Muller. Conflito de interesses nos grupos societários. São Paulo: Quartier Latin, 2006.

13 O Decreto-Lei n. 1.598 logo foi alterado pelo Decreto-Lei n. 1.648, que revogou os dispositivos que autorizavam a tributação conjunta. $O$ interessante a notar neste momento é que, em que pese respeitasse as regras dos "grupos de direito", a disposição legal trazia novos critérios para a aplicação do dispositivo aos "grupos de fato", visto que a Lei das S/A não impõe percentual de $80 \%$ do capital social para a sua caracterização. O exemplo serve para confirmar a tese da falta de sistematização na regulação do tema.

14 "Art. 33. O contribuinte com parcelamento que contenha débitos de natureza tributária, vencidos até 31 de dezembro de 2013, perante a Secretaria da Receita Federal do Brasil - RFB ou a Procuradoria-Geral da Fazenda Nacional - PGFN poderá, mediante requerimento, utilizar créditos próprios de prejuízos fiscais e de base de cálculo negativa da CSLL, apurados até 31 de dezembro de 2013 e declarados até 30 de junho de 2014, para a quitação antecipada dos débitos parcelados. $\S 1^{\circ}$ Os créditos de prejuizo fiscal e de base de cálculo negativa da CSLL poderão ser utilizados, nos termos do caput, entre empresas controladora e controlada, de forma direta ou indireta, ou entre empresas que sejam controladas direta ou indiretamente por uma mesma empresa, em 31 de dezembro de 2013, domiciliadas no Brasil, desde que se mantenham nesta condição até a data da opção pela quitação antecipada. (Vide Lei n 13.097, de 2015)." 
de créditos de prejuízos fiscais intragrupo; e (vii) o art. 30, inciso IX, da Lei n. 8.212/1991, que trata das contribuições previdenciárias e trouxe a previsão de responsabilidade solidária de empresas integrantes de grupos econômicos.

Então, dentro do quadro brasileiro de adoção ora do modelo contratual ora do modelo orgânico de classificação dos grupos econômicos, podem-se distinguir três tipos de grupo: (i) os grupos de sociedades cuja relação de domínio é formalizada contratualmente segundo os preceitos do Capítulo XXI da Lei das S/A, classificados como "grupos societários de direito"; (ii) os grupos societários cujo poder de direção se dá pelos instrumentos de controle previstos no Capítulo XX da Lei das S/A e no art. 1.097 do Código Civil (Lei n. 10.406/2002), denominados "grupos societários de fato"; e (iii) os grupos cuja relação entre os partícipes não se encontra materializada de acordo com a Lei das S/A, mas o domínio existe por outros instrumentos previstos ou não no direito, que podem ser denominados "grupos orgânicos".

O que se intitula grupo orgânico merece melhor aprofundamento. Seria esta a categoria a abarcar todas as possibilidades - lícitas ou não - de constatação de direção unitária e domínio a justificar o direcionamento das atividades dos integrantes para que seja atendido o interesse do grupo, que nem sempre converge com o interesse dos participantes individualmente considerados. O poder de direção pode ser exercido de inúmeras formas. O importante na identificação desses grupos é constatar quem, de fato, toma as decisões sobre as deliberações sociais, mesmo que não haja o instrumento jurídico adequado para tanto.

Talvez seja este o tipo mais comum de grupo econômico e aquele com o qual se preocupa grande parte da jurisprudência. Os elementos capazes de demonstrar que há um alinhamento em prol de interesses transindividuais, ou seja, que a independência das sociedades é apenas formal, são diversos, podendo-se citar a identidade de administradores e contadores, a formação de quadro societário com os mesmos indivíduos, o compartilhamento de estrutura administrativa e a atuação idêntica, complementar ou similar. ${ }^{15}$

A supracitada falta de sistematização da legislação ressalta o papel da doutrina na construção do conceito de grupo econômico, já que o direito positivo

15 FERRAGUT, Maria Rita. Responsabilidade tributária dos grupos econômicos: aumento de arrecadação em detrimento da legalidade? 22 jul. 2014. Disponivel em: <http://www.fiscosoft.com. $\mathrm{br} / \mathrm{a} / 6 \mathrm{ire} / \mathrm{responsabilidade-tributaria-dos-grupos-economicos-aumento-de-arrecadacao-em-de-}$ trimento-da-legalidade-maria-rita-ferragut>. Acesso em: 5 set. 2015. 
brasileiro não traz uma definição jurídica do que seriam esses grupamentos. Nessa esteira, deve-se concordar com a advertência de Gunther Teubner ${ }^{16}$ no sentido de que "exigências mínimas de segurança jurídica poderiam ser satisfeitas através da previsão de um conjunto de elementos típicos e fixos do conceito de grupo, comuns a todos os ramos jurídicos, designadamente em matéria de direcção unitária do grupo".

Assim, dentro do cenário do sistema jurídico brasileiro, propõe-se conceituar "grupo econômico" como o conjunto de pessoas (naturais ou jurídicas) que exercem atividade empresária, são submetidas a direção unitária, independentemente do modelo jurídico da sua formalização, e atuam em prol de um interesse do grupo que transcenda o interesse de cada uma dessas pessoas individualmente consideradas. Os elementos do grupo econômico, então, seriam: (i) o interesse de grupo; (ii) a direção unitária à qual os indivíduos estão submetidos; e (iii) a pluralidade de indivíduos exercendo atividade econômica.

O "interesse de grupo" existe quando esse interesse autônomo da sociedade individualmente considerada passa a ser potencialmente desrespeitado e a sociedade pode agir em favor de um interesse maior, o do grupo. A ideia é que o resultado global do grupo seja mais importante que o desempenho específico de um dos seus partícipes, sendo possível, inclusive, que em diversos negócios se admita o sacrifício de um em prol de todos. ${ }^{17}$ Em que pese exista autonomia em sentido jurídico dos partícipes e cada um deles venha a exercer a sua atividade, há um liame que concatena os interesses individuais e os sobrepõem para a formação do interesse de grupo.

"Direção unitária" é entendida em um conceito amplo, que representa a forma de exercício de um domínio que possibilite a coordenação das atividades dos indivíduos agrupados. Geralmente esse domínio é, em grupos societários (de fato ou de direito), decorrente do exercício do poder de controle ou influência significativa de

16 TEUBNER, Gunther. Unitas miltiplex: a organização do grupo de empresas como exemplo. Revista Direito GV, v. 1, n. 2. p. 77-100, jun.-dez. 2005.

17 "Muito mais interessante é definir o interesse social em um âmbito mais abrangente do grupo de empresas, e ali procurar organizar o feixe de contratos. Isso implica subordinar o interesse da sociedade ao interesse do grupo, desaplicando consequentemente a disciplina do conflito de interesses. É evidente que a contrapartida necessária desse fato tem de ser uma rigorosa e coerente regra de compensação das perdas causadas aos minoritários. Os minoritários, entendidos como elementos quase externos ao interesse social e à sociedade, podem ser então muito melhor defendidos por via contratual do que quando englobados no interesse social" (SALOMÃO FILHO, Calixto. O novo direito societário. 4. ed. São Paulo: Malheiros, 2015. p. 48). 
uma sociedade sobre as demais. Há, porém, outras formas lícitas ou não de se exercer o domínio. ${ }^{18} \mathrm{O}$ importante é que, uma vez verificado um conjunto de pessoas envolvidas em atividade econômica em que de algum modo é exercido o direcionamento de um integrante do grupo sobre os demais, de maneira que se possa potencialmente tangenciar o exercício dos atos da empresa contra o seu próprio interesse em prol do resultado global, pode-se dizer que se está diante de um grupo econômico.

O último e mais óbvio dos elementos caracterizadores do grupo econômico é a "pluralidade de sujeitos exercendo a atividade econômica". A obviedade vem da constatação de que grupo não pode ser formado por um só sujeito, é necessário mais de um. Neste caso, os indivíduos podem ser pessoas físicas ou jurídicas, de direito público ou privado. Os grupos podem ter entre seus partícipes fundações, associações, empresas públicas, ${ }^{19}$ autarquias, dentre outros sujeitos, como entidades beneficentes de assistência social e Organizações Não Governamentais (ONG), desde que estejam todas elas envolvidas na atividade empresarial, ainda que com desvio de finalidade, o que não é fato raro. ${ }^{20}$

\section{GRUPOS ECONÔMICOS E RESPONSABILIDADE TRIBUTÁRIA}

Uma vez explicitado de forma geral o que se entende por grupo econômico, cabe verificar em que hipótese poderia haver a responsabilização das empresas partícipes de grupos econômicos por débitos tributários.

18 Comparato denomina essas hipóteses de controle externo. COMPARATO, Fábio Konder. O poder de controle na sociedade anônima. 5 ed. atual. por Calixto Salomão Filho. Rio de Janeiro: Forense, 2008.

19 PINTO JUNIOR, Mario Engler. Organização do setor público empresarial: articulação entre Estado e companhias controladas. In: ARAUJO, Danilo Borges dos Santos Gomes de; WARDE JR., Walfrido (Coord.). Os grupos de sociedades: organização e exercício da empresa. São Paulo: Saraiva, 2012. p. 327-368.

20 "ADMINISTRATIVO. AÇÃO DE IMPROBIDADE. GESTORES DE ONG. DESVIO DE RECURSOS FEDERAIS RECEBIDOS. MANUTENÇÃO DA CONDENAÇÃO, COM LIGEIRO AJUSTE NAS PENAS QUE LHES FORAM COMINADAS. PARCIAL PROVIMENTO DA APELAÇÃO. 1. A prova dos autos é mais que suficiente para demonstrar que os gestores de certa ONG, destinatária de recursos conveniados com o Ministério da Saúde (R\$ 32.124,00), não realizaram a finalidade contratada, nem prestaram as devidas contas, senão que usaram os valores em proveito próprio; [...] 4. Manutenção das penas de ressarcimento ao erário, de multa e de proibição de contratar com o Poder Público; 5. Apelação parcialmente provida" (Processo: 00034911020104058400, AC557381/RN, Desembargador Federal Paulo Roberto de Oliveira Lima, $2^{\mathrm{a}}$ Turma, julgado em: 3 dez. 2013, DJe: 12 dez 2013). 
De início, deve-se ressaltar que responsabilizar empresas do mesmo grupo econômico é uma opção legislativa, desde que respeitados os limites legais e constitucionais existentes em cada um dos subsistemas. É prerrogativa do legislador, de acordo com o interesse a ser resguardado e protegido em determinado ramo do direito, incluir ou não na lei aplicável a determinada área a possibilidade de responsabilização das empresas do mesmo grupo econômico.

O caso mais direto de atribuição de responsabilidade tributária está no art. 30, inciso IX, da Lei n. 8.212/1991, em que se encontra previsão determinando que "as empresas que integram grupo econômico de qualquer natureza respondem entre si, solidariamente, pelas obrigações decorrentes desta Lei”. A doutrina apresentou dedicação ao tema e diversos artigos foram escritos e publicados em revistas especializadas. Identificam-se posições que podem ser divididas em três grupos: (i) os que entendem que o art. 30, inciso IX, da Lei n. 8.212/1991 é inconstitucional; ${ }^{21}$ (ii) aqueles que pensam que o referido dispositivo tem amparo no art. 124, inciso II, do Código Tributário Nacional (CTN), sendo plenamente constitucional e aplicável, ${ }^{22}$ e, finalmente, (iii) aqueles que entendem que a solidariedade da lei ordinária há de ser interpretada dentro dos limites do CTN. ${ }^{23}$

Entende-se, na esteira da primeira corrente, que a atribuição de responsabilidade tributária é tema que a Constituição Federal (CF) de 1988 reservou à lei complementar, razão pela qual a norma do art. 30, inciso IX, da Lei n. 8.212/1991, que tem natureza de lei ordinária, padece de vício formal, não podendo ser aplicada

21 "Sendo assim, é ilegítimo, ilegal, inconstitucional, arbitrário, aético e imoral o procedimento da Administração Fazendária de alargar as hipóteses de responsabilidade tributária previstas no CTN, adotando o conceito de 'grupo econômico', tal qual como delineado na legislação trabalhista (art. $2^{\circ}$, parágrafo $2^{\circ}$ da CLT)" (MARTINS, Ives Gandra. Grupos econômicos e responsabilidade tributária. Revista Dialética de Direito Tributário, n. 236. São Paulo: Dialética, 2015. p. 101.

22 Dentre os autores que entendem pela constitucionalidade do art. 30, inciso IX, da Lei n. 8.212/1991, pode-se citar Lucas Fonseca de Mello, para quem o art. 124, inciso II, do CTN daria respaldo para a lei ordinária tratar do tema, bastando a hipótese estar prevista na lei, sem necessariamente encontrar base em outro dispositivo do CTN (MELLO, Lucas Fonseca de. Responsabilidade tributária de fundos de private equity e venture capital. Revista Dialética de Direito Tributário, n. 192. São Paulo: Dialética, 2011.

23 Renato Lopes Becho entende que o art. 30, inciso IX, da Lei n. 8.212/1991 deve ser interpretado sistematicamente, conforme os contornos do CTN, de modo que a aplicação da lei ordinária seria possivel desde que "as empresas envolvidas do mesmo grupo econômico tenham atuado conjuntamente, de alguma forma, para permitir que o fato gerador em concreto tenha sido realizado" (BECHO, Renato Lopes. A responsabilização tributária de Grupo Econômico. Revista Dialética de Direito Tributário, n. 221. São Paulo: Dialética, 2014. p. 136. 
diante da evidente inconstitucionalidade que carrega. Assim, não poderia haver a responsabilização tributária por grupos econômicos com fundamento neste dispositivo legal. ${ }^{24}$

Outra situação hipotética aventada para a responsabilização de empresas partícipes de grupos econômicos seria a aplicação do art. 124, inciso I, do CTN. Essa possibilidade ganhou relevância principalmente em virtude dos inúmeros casos levados ao judiciário e julgados pelo Superior Tribunal de Justiça (STJ). Ausente previsão expressa do CTN de responsabilidade dos grupos e havendo disposição em lei ordinária (inconstitucional) para o caso, passou-se a propor que o "interesse comum na situação que constitua o fato gerador do tributo" englobasse também os casos em que há um benefício econômico decorrente das atividades da empresa. Se as atividades empresariais que constituem fato gerador dos tributos beneficiam indiretamente todo o grupo econômico, deveria ele ser responsabilizado.

Essa tentativa não encontrou guarida no judiciário nem na doutrina. ${ }^{25} \mathrm{~A} 1^{\mathrm{a}}$ Sessão do STJ, no julgamento dos embargos de divergência no Recurso Especial (REsp) n. 834.044/RS, confirmou o entendimento de que a aplicação do art. 124, inciso I, do CTN poderia se dar apenas nos casos em que houvesse interesse jurídico comum no fato gerador do tributo, tendo definido que o simples fato de empresas pertencerem ao mesmo grupo econômico não seria suficiente para estender a responsabilidade para todo o grupo.

Restaria, então, como fundamento para responsabilização de empresas pertencentes ao mesmo grupo econômico a aplicação do art. 50 da Lei n. 10.406/2002 (Código Civil). A desconsideração da personalidade jurídica fulcrada no dispositivo não é propriamente um tema de direito tributário, pelo que a doutrina da área pouco se ocupa da temática especificamente em relação aos grupos econômicos.

24 O mesmo entendimento foi perfilhado no supracitado julgamento, pelo Supremo Tribunal Federal, do RE n. 562.276/PR, quando o art. 13 da Lei n. 8.620/1993 foi declarado inconstitucional.

25 Neste sentido: MARTINS, Ives Gandra. Grupos econômicos e responsabilidade tributária. Revista Dialética de Direito Tributário, n. 236. São Paulo: Dialética, 2015; FERRAGUT, Maria Rita. Grupos econômicos e solidariedade tributária. Revista Dialética de Direito Tributário, n. 229. São Paulo: Dialética, 2014; COELHO, Sacha Calmon Navarro. O sujeito passivo da obrigação tributária. Revista Dialética de Direito Tributário, n. 240. São Paulo: Dialética, 2015; BECHO, Renato Lopes. A responsabilização tributária de Grupo Econômico. Revista Dialética de Direito Tributário, n. 221. São Paulo: Dialética, 2014. 
Encontram-se em Maria Rita Ferragut, ${ }^{26}$ Renato Lopes Becho ${ }^{27}$ e Ramon Tomazela Santos ${ }^{28}$ manifestações em favor da aplicação do art. 50 do Código Civil aos grupos econômicos, desde que constatado - e comprovado pelo fisco - um dos seus requisitos ínsitos: o abuso de personalidade ou a confusão patrimonial. Os autores são unânimes em ressaltar que não se trata de hipótese de responsabilidade tributária e que a aplicação não pode se dar unicamente pela constatação da existência de grupo econômico de fato ou de direito.

Há, contudo, oposições à aplicação da desconsideração da personalidade jurídica em matéria tributária, tendo em vista a reserva de lei complementar estatuída pelo art. 146, inciso III, do texto constitucional. ${ }^{29-30}$ Em que pesem respeitáveis as posições contrárias, entende-se que a aplicação do art. 50 do Código Civil é a única hipótese no ordenamento jurídico brasileiro que autoriza que um terceiro seja instado a responder pelo pagamento de tributos quando da participação em grupo econômico, mas é importante tecer alguns esclarecimentos.

26 FERRAGUT, Maria Rita. Grupos econômicos e solidariedade tributária. Revista Dialética de Direito Tributário, n. 229. São Paulo: Dialética, 2014.

27 BECHO, Renato Lopes. A responsabilização tributária de Grupo Econômico. Revista Dialética de Direito Tributário, n. 221. São Paulo: Dialética, 2014.

28 SANTOS, Ramon Tomazela. Responsabilidade tributária e grupo econômico. Revista Dialética de Direito Tributário, n. 238. São Paulo: Dialética, 2015.

29 Neste sentido, Luciano Amaro: "Resta examinar a desconsideração da pessoa jurídica (propriamente dita), que seria feita pelo juiz, para responsabilizar outra pessoa (o sócio), sem apoio em prévia descrição legal de hipótese de responsabilização do terceiro, à qual a situação concreta pudesse corresponder. Nessa formulação teórica da doutrina da desconsideração não vemos possibilidade de sua aplicação em nosso direito tributário. Nas diversas situações em que o legislador quer levar a responsabilidade tributária além dos limites da pessoa jurídica, ele descreve as demais pessoas veiculadas ao cumprimento da obrigação tributária. Trata-se, ademais, de preceito do próprio Código Tributário Nacional, que, na definição do responsável tributário, exige norma expressa de lei (arts. 121, parágrafo único, II, e 128), o que, aliás, representa decorrência do princípio da legalidade. Sem expressa disposição de lei, que eleja terceiro como responsável em dadas hipóteses descritas pelo legislador, não é lícito ao aplicador da lei ignorar (ou desconsiderar) o sujeito passivo legalmente definido e imputar a responsabilidade tributária a terceiro" (AMARO, Luciano. Direito Tributário Brasileiro. 10. ed. São Paulo: Saraiva, 2004. p. 236).

30 No mesmo sentido: "Entretanto, a desconsideração da personalidade jurídica não poderia ser aplicada nos lindes tributários, em razão de não provir de lei complementar" (MELO, José Eduardo Soares de. A desconsideração da personalidade jurídica no Código Civil e reflexo no Direito Tributário. In: GRUPENMACHER, Betina Treiger (Coord.). Direito Tributário e o Novo Código Civil. São Paulo: Quartier Latin, 2004. p. 166. 
O primeiro ponto a se notar quando da aplicação do art. 50 do Código Civil para a teoria da desconsideração da personalidade jurídica das sociedades em matéria tributária é que não se está tratando do tema responsabilidade tributária, cujos pressupostos de aplicação são distintos. ${ }^{31}$ Em matéria de responsabilidade tributária, os responsáveis obrigatoriamente precisam ter relação com o fato gerador do tributo e é necessária designação em lei complementar, cumprindo os requisitos constitucionais para tanto. $\mathrm{Na}$ desconsideração da personalidade jurídica, ao revés, se possibilita o alcance dos bens de sócios e administradores - de outras sociedades no caso de desconsideração inversa - pela constatação do abuso de personalidade ou de confusão patrimonial.

É importante afirmar que a limitação da responsabilidade dos sócios não é característica inerente à pessoa jurídica, é uma concessão da legislação societária, posta por lei ordinária, para alguns tipos societários. Da mesma forma que a lei define as hipóteses em que há limites à responsabilidade, ela também pode trazer pressupostos para que se afaste a limitação.

Outra anotação é relevante: a desconsideração da personalidade jurídica não tem nenhum tipo de aplicação especial em relação aos grupos econômicos; ela é, em verdade, uma teoria aplicável a todos os casos em que se constate abuso de personalidade, caracterizado pelo desvio de finalidade ou confusão patrimonial. Pode ser que haja, em grupos econômicos, a prática desses atos, mas o ponto é que não se pode generalizar e dizer que sempre que se constatar a existência de grupos, de fato, de direito ou mesmo orgânicos, estarão presentes os pressupostos para desconsideração da personalidade jurídica.

Em grupos societários de direito, por sua própria essência, os atos praticados em prejuízo de alguma das sociedades pertencentes ao conglomerado em prol do interesse do grupo não se caracteriza como abuso de personalidade para fins de aplicação da teoria da desconsideração da personalidade jurídica, já que há autorização na legislação para tanto.

31 Sobre o tema, Humberto Theodoro Jr. asseverou: "Na verdade, não se pode falar em desconsideração da personalidade juridica, quando pela lei já existe uma previsão expressa de responsabilidade direta do sócio. Em tal caso, a obrigação é originalmente do sócio, mesmo que tenha praticado ato na gestão social. A teoria do disregard não foi concebida visando este tipo de responsabilidade solidária ou direta, mas para aqueles casos em que a pessoa jurídica se apresenta como um obstáculo a ocultar os verdadeiros sujeitos do ato fraudulento praticado em nome da sociedade, mas em proveito pessoal do sócio" (THEODORO JR., Humberto. Partes e terceiros na execução. In: O processo civil no limiar do novo século. Rio de Janeiro: Forense, 1999). 
Já nos grupos de fato ou orgânicos, a prática de atos em prejuízo de qualquer das empresas partícipes, caso não haja a previsão de compensação dos prejuízos a legitimá-lo, pode ser encarada como desvio de finalidade, ilícito que se enquadra no conceito de abuso de personalidade apto a ensejar a aplicação da disregard doctrine. Como já visto, essas práticas são possíveis, mas não regra em grupos econômicos. Por essa razão, é muito importante que não se generalize a aplicação do instituto nem se crie a falsa presunção de que, sempre que houver um grupo econômico orgânico ou de fato, há desvio de finalidade ou confusão patrimonial. A prova do fato concreto de que houve abuso é de responsabilidade do fisco e a lei não traz qualquer presunção.

Isso não quer dizer que as empresas pertencentes ao mesmo grupo não possam aproveitar a sinergia gerada pela integração dos negócios. Os simples fatos de utilizar os serviços do mesmo contador ou advogado, possuir o mesmo endereço, partilhar instalações, linhas telefônicas ou site, ou apresentar-se publicamente como grupo em material publicitário, dentre outras condutas geralmente levantadas pelo fisco para comprovar a confusão patrimonial, não podem ser levadas em conta se há a devida contraprestação pelos serviços e pela utilização do patrimônio da outra empresa.

Neste ponto, é importante que se ressalte que a própria Cosit reconhece que, como se depreende da Solução de Divergência n. 23/2012, ${ }^{32}$

é possível a concentração, em uma única empresa, do controle dos gastos referentes a departamentos de apoio administrativo centralizados, para posterior rateio dos custos e despesas administrativos comuns entre empresas que não a mantenedora da estrutura administrativa concentrada.

Até a gestão de caixa unificada dentro do grupo é admitida. Ou seja, desde que observados determinados cuidados para que o rateio de custos se dê de forma

32 "ASSUNTO: IMPOSTO SOBRE OPERAÇÕES DE CRÉDITO, CÂMBIO E SEGUROS OU RELATIVAS A TÍTULOS OU VALORES MOBILIÁRIOS IOF. RECURSOS DA CONTROLADA EM CONTA DA CONTROLADORA. CONTA CORRENTE. RAZÃO DE SER DA HOLDING. Os recursos financeiros das empresas controladas que circulam nas contas da controladora não constituem de forma automática a caracterização de mútuo, pois dentre as atividades da empresa controladora de grupo econômico está a gestão de recursos, por meio de conta corrente, não podendo o Fisco constituir uma realidade que a lei expressamente não preveja. Recurso Voluntário Provido" (Acórdão $\mathrm{n}$. 3101001.094, 1ª Câmara, $1^{\text {a }}$ Turma Ordinária, publicado em: 4 jul. 2013). 
regular, não se pode dizer que há abuso de personalidade apto a ensejar a aplicação da disregard doctrine pela simples presença de compartilhamento de ativos e serviços.

\section{EXECUÇÕES FISCAIS E OS PROBLEMAS INERENTES AO REDIRECIONAMENTO}

A execução de dívidas feita pela Fazenda Pública corre segundo rito especial da Lei n. 6.830/1980 (Lei de Execuções Fiscais - LEF), tendo o Código de Processo Civil (CPC) aplicação subsidiária.

Via de regra, em relação aos tributos, após a constituição da obrigação pelo contribuinte ou pelo ente da administração pública e a apuração dos responsáveis, o débito é encaminhado para inscrição em dívida ativa pela Procuradoria Fiscal, que forma o título executivo extrajudicial (Certidão de Dívida Ativa - CDA), que instruirá o processo visando à expropriação de bens do devedor para a satisfação do crédito.

A execução fiscal, então, é proposta contra o devedor, o fiador, o espólio, a massa falida, o responsável pessoa física ou jurídica, ou os sucessores, contra os quais o débito já deveria ter sido constituído em momento anterior, quando o sujeito apontado como obrigado a pagar o débito - contribuinte ou responsável - deveria ter sido intimado para participar do processo administrativo e, em atenção ao art. $5^{\circ}$, incisos LIV e LV, da CF de 1988, exercido amplamente a sua defesa, respeitando-se o contraditório e o devido processo legal. Este tema - a obrigatoriedade de submissão prévia ao contraditório do lançamento contra codevedores - já foi alvo de análise pelo Supremo Tribunal Federal (STF), ${ }^{33}$ que prolatou decisão no sentido de que o contraditório é essencial para a validade da imputação de responsabilidade.

$\mathrm{O}$ art. 202 do CTN e o art. $2^{\circ}$, $\ 5^{\circ}$, inciso I, da LEF determinam a inclusão dos corresponsáveis na CDA, e o art. 779, inciso VI, do CPC vigente inclui o responsável tributário como sujeito passivo da execução, o que permite que esta seja promovida contra o responsável. Quando, após a citação na execução fiscal, o sujeito deseja resistir à pretensão fazendária, lhe é facultado, depois da garantia do feito, apresentar embargos à execução, em que poderá rediscutir o débito e a sua própria legitimidade passiva. Não sendo necessária a produção de provas, as matérias de

33 STF, RE n. 608426 AgR, Rel. Min. Joaquim Barbosa, 2a Turma, julgado em: 4 out. 2011, DJe: 21 out. 2011, publicado em: 24 out. 2011. 
ordem pública podem ser defendidas por exceção de pré-executividade, o que permite ao devedor se opor à execução fiscal sem dispender recursos com a garantia. ${ }^{34}$

Ocorre que a prática dos tribunais tem revelado que algumas situações fogem à regra geral de apuração prévia da sujeição passiva, principalmente quando de responsabilidade por transferência, muito comum em caso de sucessão empresarial e responsabilidade dos administradores, bem como da constatação de abuso de personalidade jurídica. Nessas hipóteses, o fato que enseja a obrigação de pessoas que não o devedor original pode ocorrer ou ser constatado em momento posterior ao ajuizamento da execução fiscal ou da inscrição em dívida ativa. Quando o fato é constatado antes do ajuizamento da ação, a Procuradoria Fiscal, autorizada pela Portaria da Procuradoria-Geral da Fazenda Nacional (PGFN) n. 180/2010, retifica as CDA para inclusão dos codevedores. ${ }^{35}$

Em setembro de 2017, a Procuradoria da Fazenda Nacional, por meio da Portaria PGFN n. 948, regulamentou o que se denomina "Procedimento Administrativo de Reconhecimento de Responsabilidade" (PARR), aplicável apenas ao caso de responsabilização de terceiros pela prática de dissolução irregular da pessoa jurídica devedora, o que é considerado infração à lei para efeitos de aplicação do art. 135 do CTN. Embora criticável pelo fato de o julgamento ser realizado pela própria PGFN, o PARR é um avanço no exercício do devido processo legal na esfera administrativa que deve ser estendido às demais hipóteses de responsabilidade.

Caso o processo já esteja em trâmite, a jurisprudência criou a figura do redirecionamento das execuções fiscais, que nada mais é que a inclusão no polo passivo do feito executivo de pessoas não originalmente executadas. Juliana Furtado

34 STJ: "A exceção de pré-executividade é admissivel na execução fiscal relativamente às matérias conheciveis de oficio que não demandem dilação probatória” (Súmula 393, 1ª Seção, julgado em: 23 set. 2009, DJe: 7 out. 2009).

35 Portaria PGFN n. 180/2010: "Art. 4. Após a inscrição em divida ativa e antes do ajuizamento da execução fiscal, caso o Procurador da Fazenda Nacional responsável constate a ocorrência de alguma das situações previstas no art. $2^{\circ}$, deverá juntar aos autos documentos comprobatórios e, após, de forma fundamentada, declará-las e inscrever o nome do responsável solidário no anexo Il da Certidão de Dívida Ativa da União. Art. $5^{\circ}$. Ajuizada a execução fiscal e não constando da Certidão de Dívida Ativa da União o responsável solidário, o Procurador da Fazenda Nacional responsável, munido da documentação comprobatória, deverá proceder à sua inclusão na referida certidão. Parágrafo único. No caso de indeferimento judicial da inclusão prevista no caput, o Procurador da Fazenda Nacional interporá recurso, desde que comprovada, nos autos judiciais, a ocorrência de uma das hipóteses previstas no art. $2^{\circ}$ desta Portaria." 
Costa Araujo $^{36}$ entende que os incisos I e V do art. 568 do CPC possibilitam o redirecionamento "se a responsabilidade destes terceiros não está configurada quando do ajuizamento do feito executivo, sendo que no decorrer do processo de execução ela vem à tona". A jurisprudência do STJ já consolidou o entendimento pelo cabimento do redirecionamento das execuções fiscais, como se verifica da Súmula $435 .{ }^{37}$

Porém, a questão fica ainda mais complicada quando se verifica que o redirecionamento da execução fiscal ou a inclusão do suposto responsável na CDA, salvo na hipótese de dissolução irregular, ocorre sem que haja qualquer oportunidade de defesa, de modo que o conhecimento da imputação só acontece quando do recebimento do mandado de citação para pagar o débito. Não fosse o bastante, a jurisprudência que se consolidou no STJ autoriza o redirecionamento da execução e ainda inverte o ônus da prova quando o nome do corresponsável consta da $\mathrm{CDA},{ }^{38}$ vedando ainda a apresentação de exceção de pré-executividade.

Assim, antes de apresentar qualquer defesa em esfera judicial ou administrativa, o suposto codevedor se vê obrigado a suportar o ônus de garantir a execução e tem a certidão de regularidade fiscal negada e o nome inscrito no Cadastro Informativo de Créditos não Quitados do Setor Público Federal (Cadin), podendo inclusive sofrer com protestos. É uma situação frontalmente violadora do devido

36 ARAUJO, Juliana Furtado Costa. O prazo para redirecionamento da ação de execução fiscal em face de terceiros responsáveis. Revista da PGFN, ano I, n. 1. Brasília: PGFN, 2011, p. 86.

37 STJ: "Presume-se dissolvida irregularmente a empresa que deixar de funcionar no seu domicílio fiscal, sem comunicação aos órgãos competentes, legitimando o redirecionamento da execução fiscal para o sócio-gerente" (Súmula 435, 1ª Seção, julgado em: 14 abr. 2010, DJe: 13 maio 2010).

38 "TRIBUTÁRIO. EXECUÇÃO FISCAL SÓCIO-GERENTE CUJO NOME CONSTA DA CDA. PRESUNÇÃO DE RESPONSABILIDADE. ILEGITIMIDADE PASSIVA ARGUIDA EM EXCEÇÃO DE PRÉ-EXECUTIVIDADE. INVIABILIDADE. PRECEDENTES. 1. A exceção de pré-executividade é cabivel quando atendidos simultaneamente dois requisitos, um de ordem material e outro de ordem formal, ou seja: (a) é indispensável que a matéria invocada seja suscetivel de conhecimento de ofício pelo juiz; e (b) é indispensável que a decisão possa ser tomada sem necessidade de dilação probatória. 2. Conforme assentado em precedentes da Seção, inclusive sob o regime do art. 543-C do CPC (REsp 1104900, Min. Denise Arruda, sessão de 25.03.09), não cabe exceção de pré-executividade em execução fiscal promovida contra sócio que figura como responsável na Certidão de Dívida Ativa - CDA. É que a presunção de legitimidade assegurada à CDA impõe ao executado que figura no título executivo o ônus de demonstrar a inexistência de sua responsabilidade tributária, demonstração essa que, por demandar prova, deve ser promovida no âmbito dos embargos à execução. 3. Recurso Especial provido. Acórdão sujeito ao regime do art. 543-C do CPC" (REsp n. 1110925/SP, Rel. Min. Teori Albino Zavascki, 1ª Seção, julgado em: 22 abr. 2009, DJe: 4 maio 2009). 
processo legal, e é exatamente o que ocorre quando o juízo das varas de execução fiscal autoriza o redirecionamento dos feitos para os grupos econômicos.

A ausência de processo administrativo prévio ou procedimento judicial que venha a possibilitar a ampla defesa e o contraditório nos casos de redirecionamento de execução fiscal para os codevedores é idêntica à constatação de abuso de personalidade jurídica: não há qualquer contraditório prévio à decisão que reconhece a confusão patrimonial ou desvio de finalidade, de modo que o suposto devedor primeiro sofre o ônus da responsabilização para depois se defender. Não custa lembrar que a desconsideração da personalidade jurídica é sanção, ${ }^{39}$ que nesse caso vem sendo aplicada ao arrepio da CF, em completa desatenção aos princípios do devido processo legal, da ampla defesa e do contraditório.

Isto posto, resta averiguar como a sanção do Novo Código de Processo Civil (NCPC) traz nova luz ao tema por meio do IDPJ e se a sua aplicação mitigará o problema alhures apontado.

\section{O IDPJ NO NCPC E A SUA APLICABILIDADE NAS EXECUÇÕES FISCAIS}

Foi visto que a jurisprudência relativa às execuções fiscais permitia que o exequente requeresse o redirecionamento da cobrança para os responsáveis tributários

39 Maria Rita Ferragut bem observou a situação, constatando haver "terrivel patologia de nosso sistema processual, que, ao não aceitar a exceção de pré-executividade como meio de defesa do responsável tributário, e tampouco prever qualquer outra forma de defesa prévia, faz com que pessoas juridicas alegadamente integrantes de grupos econômicos tenham que aguardar muitos anos para ter seus argumentos e provas apreciados nos autos dos embargos à execução fiscal. Afora isso, essas pessoas sujeitam-se à necessidade de oferecimento de bens para garantia do débito, BACEN-JUD, certidão positiva de débitos, provisionamento da divida etc. O efeito, muitas vezes, é devastador. O Poder Judiciário resiste a aceitar a exceção de pré-executividade como meio de defesa prévia das pessoas juridicas corresponsabilizadas, por entender, com base na Súmula 393 do STJ (01), que a exceção é incabivel para a exclusão do responsável, tendo em vista a necessidade de dilação probatória. Atualmente resta a esses contribuintes o lento e oneroso caminho dos embargos à execução fiscal, em indiscutivel mitigação do direito constitucional ao contraditório, que não é meramente formal, e que não nos parece ter sido assegurado somente pela possibilidade de oposição de embargos à execução fiscal" (FERRAGUT, Maria Rita. Novo CPC: o incidente de desconsideração da personalidade jurídica tornando efetivo o direito dos grupos econômicos oferecerem o contraditório. Disponivel em: <http://www.fiscosoft.com.br/a/6rd8/novo-cpc-o-incidente-de-desconsideracao-da-personalidade-juridica-tornando-efetivo-o-direito-dos-grupos-economicos-exercerem-o-contraditorio-maria-rita-ferragut>. Acesso em: 11 maio 2015. 
ou solicitasse ao juízo a desconsideração da personalidade jurídica do executado quando entendesse presentes os requisitos legais necessários para tanto e que, se convencido, o juiz poderia determinar a inclusão dessas pessoas no polo passivo da execução fiscal (no caso de responsabilidade), ou que os bens de sócios e administradores fossem alcançados para o pagamento da dívida (no caso de desconsideração da personalidade jurídica), sem que houvesse qualquer tipo de contraditório prévio. Ou seja, aplicava-se uma sanção sem a observância do devido processo legal.

A edição do NCPC trouxe nova luz ao tema quando previu, nos art. 133 a 137, o IDPJ. Cabe, então, analisar a compatibilidade do novo incidente com o rito das execuções fiscais e sua utilização nos casos de reconhecimento da responsabilidade de membros de grupo econômico com esteio no art. 50 do Código Civil.

A LEF prevê, no seu art. $1^{\circ}$, a aplicação subsidiária do CPC na execução judicial para a cobrança da dívida ativa dos entes federativos. O NCPC prevê expressamente, no $\ 4^{\circ}$ do art. 146, que "as remissões a disposições do Código de Processo Civil revogado, existentes em outras leis, passam a referir-se às que lhes são correspondentes neste Código", de modo que não há dúvidas sobre a aplicação subsidiária do NCPC à LEF.

O pleito de instauração do incidente é cabível em todas as fases do processo, inclusive na execução fundada em título executivo extrajudicial, que é o caso das execuções fiscais, ou em fase recursal, como se depreende do art. 932 do NCPC. ${ }^{40}$ Cabe, ainda, em processos de competência dos juizados especiais (art. 1.062).

A partir da entrada em vigor do NCPC, toda vez que constatar a presença dos pressupostos para a desconsideração da personalidade jurídica, o exequente ou o Ministério Público deve requerer ao juízo a instauração do incidente, quando o imputado terá a oportunidade de apresentar defesa e requerer as provas cabíveis no prazo de 15 dias. Desse modo, se vê preservado o devido processo legal, já que se desfaz a presunção de culpabilidade contra o pretenso devedor, que poderá se defender de forma ampla antes de ter contra si aplicada a sanção e sem a necessidade de garantir previamente o feito.

É de se notar que de forma alguma os direitos do exequente são preteridos. É que, uma vez constatada a possibilidade de dilapidação do patrimônio ou fraude à execução, o representante da Fazenda poderá solicitar tutela de urgência no

40 "Art. 932. Incumbe ao relator: [...] VI - decidir o incidente de desconsideração da personalidade juridica, quando este for instaurado originariamente perante o tribunal." 
próprio incidente, conforme regras do art. 300 e seguintes do NCPC que tratam da tutela de urgência e são plenamente aplicáveis.

Um ponto a se notar é o quanto disposto no $\ 4^{\circ}$ do art. 134 , que diz que o "requerimento deve demonstrar o preenchimento dos pressupostos legais específicos para desconsideração da personalidade jurídica". A dúvida que surge é se a prova de confusão patrimonial ou desvio de finalidade da sociedade deve ser pré-constituída ou se o exequente poderá requerer a produção de novas provas no incidente. Entende-se que a parte que pretender obter a instauração do incidente deve juntar indícios suficientes para convencer o juízo de que o tema merece investigação aprofundada e, de logo, indicar as novas provas a serem produzidas.

Há também de se verificar a regra do $\ 2^{\circ}$ do art. 134, que possibilita ao exequente dispensar a instauração do incidente se a desconsideração da personalidade jurídica for requerida na petição inicial. O que parece é que a hipótese se aplica apenas à inicial do processo de conhecimento, já que, ao longo do processo de cognição ampla, o terceiro poderá se defender. Não se poderia admitir outra interpretação do artigo, sob pena de ferimento do devido processo legal, já que impor sanção a terceiro que não participou da formação do título sem que a defesa fosse oportunizada seria incompatível com a CF por violação ao contraditório.

Neste ponto, o caso da execução fiscal é mais grave que o das outras execuções de título extrajudicial. É que o terceiro em execuções de título extrajudicial pode opor embargos independentemente do ônus de garantia do juízo (art. 914, NCPC), enquanto na execução fiscal é imprescindível essa providência, nos termos do $\int 1^{\circ}$ do art. 16 da LEF. Assim, não é possível a dispensa da instauração do incidente com o requerimento de desconsideração da personalidade jurídica na petição inaugural da execução fiscal.

É importante não confundir o pedido de desconsideração da personalidade jurídica deduzido na inicial com a inclusão do sujeito na CDA. Na hipótese de presença do nome do corresponsável no título, não há de se falar em desconsideração da personalidade jurídica, sendo o mesmo co-obrigado e diretamente executado.

Lembremos que, nos termos do art. 50 do Código Civil, a desconsideração da personalidade só pode ser decretada por um juiz. O que é necessário averiguar nesses casos é se houve a participação do co-obrigado no processo administrativo fiscal que ensejou a formação do título. Se não houve, e o título foi formado unilateralmente e sem a observância do devido processo legal, o que há é a sua nulidade, que deve ser arguida por exceção de pré-executividade ou embargos à execução.

É interessante destacar que o referido incidente é apto para a obtenção de provimento judicial que permita a desconsideração da personalidade jurídica para 
atingir o patrimônio dos sócios, bem como as demais empresas que tenham por ele sido utilizadas para frustrar a execução ou com a qual tenha havido confusão patrimonial, por meio da desconsideração inversa. É essa, de forma geral, a hipótese que contempla a possibilidade de atingir os bens dos demais partícipes dos grupos econômicos, inclusive nos casos em que há o controle por meio de pessoas e sociedades interpostas, ou outros métodos fraudulentos.

Também é de fundamental importância para a compreensão da processualística da desconsideração da personalidade reforçar a distinção entre a aplicação da disregard doctrine e da responsabilidade tributária. Sob o ponto de vista processual, o responsável é parte do processo, enquanto o sócio ou administrador da empresa cuja personalidade foi desconsiderada apenas responde pela dívida com seu patrimônio, não integrando a lide, de modo a ser tratado como terceiro. Essa ideia é reforçada pela localização do IDPJ no próprio NCPC: Capítulo IV, Título III, que trata justamente da intervenção de terceiros. Quando se tratar de desconsideração da personalidade jurídica, portanto, caso não seja instaurado o incidente, o administrador ou sócio da empresa deverá opor-se via embargos de terceiros, não embargos à execução. ${ }^{41}$

O que se lamenta é que o incidente tenha pressuposto muito específico: é utilizável apenas nos casos de desconsideração da personalidade jurídica, e não nas outras hipóteses de constatação de responsabilidade por transferência em virtude de atos praticados ou descobertos ao longo da tramitação do processo de execução. Nesses casos, a inaplicabilidade do incidente é defensável, já que esse responsável não é terceiro, mas parte do processo. Não havendo a aplicação da disregard doctrine, não há de se falar em aplicação do incidente. ${ }^{42}$

Como se defende que a responsabilização dos grupos econômicos por débitos de natureza tributária só poderá ocorrer pela desconsideração da personalidade jurídica, pode-se concluir que o incidente de desconsideração da personalidade jurídica previsto no NCPC acaba por resolver grave lesão ao direito de defesa e à presunção de inocência que ocorria nos redirecionamentos de execuções fiscais.

41 FERRAGUT, Maria Rita. Incidente de desconsideração da personalidade juridica e os grupos econômicos. In: CONRADO, Paulo Cesar; ARAUJO, Juliana Furtado Costa (Org.). O Novo CPC e seu impacto no direito tributário. São Paulo: Fiscosoft, 2015.

42 CANTANHEDE, Luis Claudio Ferreira. O redirecionamento à execução fiscal em virtude do encerramento irregular da sociedade executada e o incidente de desconsideração da personalidade jurídica. In: CONRADO, Paulo Cesar; ARAUJO, Juliana Furtado Costa (Org.). O Novo CPC e seu impacto no direito tributário. São Paulo: Fiscosoft, 2015. 
As empresas partícipes de grupos econômicos que porventura tenham seus patrimônios afetados pela desconsideração da personalidade jurídica de outra empresa do grupo em execução fiscal podem, finalmente, exercer o direito de defesa antes de sofrer sanção.

\section{CONSIDERAÇÕES FINAIS}

Ante todo o exposto, concluímos que a aplicação da teoria da desconsideração da personalidade jurídica é o único caso em que se possibilita a responsabilização de empresas partícipes de grupos econômicos por débitos tributários, razão pela qual o incidente de desconsideração da personalidade jurídica trazido pelo NCPC, compatível com o rito especial da LEF, deve ser obrigatoriamente utilizado nesses casos.

Permanece, contudo, a esdrúxula situação em relação aos redirecionamentos de execução fiscal fundados em responsabilidade, para os quais o novo incidente é inaplicável e o executado sofre as agruras do processo executório sem que tenha sido oportunizada a defesa prévia. 
